\title{
HOW CAN ADVANCED INFORMATION AND COMMUNICATION TECHNOLOGY SUPPORT CORPORATE ENVIRONMENTAL PERFORMANCE?
}

\author{
HOGYAN TUDJA A FEJLETT INFORMÁCIÓS ÉS \\ KOMMUNIKÁCIÓS TECHNOLÓGIA TÁMOGATNI A VÁLLALATOK \\ KÖRNYEZETI TELJESÍTMÉNYÉT?
}

In this paper the authors investigate the relationship of advanced information and communication technology (ICT) use and the environmental performance on the company level. Their presumption is that companies with advanced ICT can have better environmental performance as well. The level of ICT development is assessed by Pham's model, while environmental performance is interpreted along with the model of Schultze and Trommer. The authors tested the models and the relationship of ICT and environmental performance by statistical analysis, using the database of Hungarian Competitiveness Research Centre. Regarding the results, there is a positive connection between high-level ICT use and environmental performance in many aspects. Since advanced ICT allows companies to gather and analyze data extensively, the monitoring of the environmental performance indicators and the intervention, continuous development can be more efficient. Environmental sustainability is not the privilege of large companies, middle size companies are also intensely dealing with this important issue.

Keywords: environmental performance, ICT, information technology, sustainability

Tanulmányukban a szerzők a vállalatok magas szintű információs és kommunikációs technológiákban (ICT) való jártassága és környezeti teljesítménye közötti kapcsolatot vizsgálják. Feltételezéseik szerint azok a vállalatok, amelyek fejlett ICT-t alkalmaznak, környezeti szempontból is jobban teljesítenek. Az ICT fejlettséget Pham modellje segítségével mérik, míg a környezeti teljesítmény megítéléséhez Schultze és Trommer megközelítését alkalmazzák. A modelleket és a fent felvázolt összefüggést statisztikai módszerekkel tesztelték, amelyhez a Versenyképességkutatás adatbázisát használták fel. Az eredményeket tekintve elmondható, hogy pozitív kapcsolat van a vállalatok ICT-fejlettsége és környezeti teljesítménye között több szempontból is. Mivel a fejlett ICT jobb adatgyűjtést és elemzést tesz lehetővé, a környezeti teljesítmény mérése és a beavatkozás is hatékonyabb lehet. A felelős környezeti gondolkodás nem csak a nagyvállalatok privilégiuma, a középvállalatok is élénken foglalkoznak a témával. A magántulajdonban lévő vállalatok környezeti teljesítménye jellemzően jobb, mint az állami tulajdonban lévőké.

Kulcsszavak: környezeti teljesítmény, ICT, információtechnológia, fenntarthatóság

Funding/Finanszírozás:

The authors did not receive any grant or institutional support in relation with the preparation of the study.

\section{Authors/Szerzők:}

Dr. Judit Nagy, PhD, associate professor, Corvinus University of Budapest (judit.nagy@uni-corvinus.hu)

Dr. Orsolya Diófási-Kovács, PhD, assistant professor, Corvinus University of Budapest (orsolya.diofasi@uni-corvinus.hu)

This article was received: 16. 09. 2020, revised: 19. 10. 2020, accepted: 21. 10. 2020.

A cikk beérkezett: 2020. 09. 16-án, javítva: 2020. 10. 19-én, elfogadva: 2020. 10. 21-én. 
Tnformation technology, industrial digitalization, robotics, sustainability, circular economy, ecoefficiency - topics that raise the interest of researchers and professionals as well, and the success of the concepts also determine our future. Nowadays managers have to adapt to a highly dynamic business environment. According to the concept of dynamic capabilities (Eisenhardt \& Martin, 2000) in order to cope with the dynamic environment, businesses need to acquire relevant knowledge, then transform them into capabilities and finally, use these capabilities to gain and sustain competitive advantage (Zahra \& George, 2002).

This environment is determined by two concepts nowadays: sustainability - as demand from stakeholders at large (Seth, Sethia \& Srinivas, 2011; Seuring \& Müller, 2008; Kraus, Rehman \& García, 2020) - and digitalization which has the potential to boost efficiency and provide better customer service of the companies (Becker, Knackstedt \& Pöppelbuß, 2009; Lenka, Parida \& Wincent, 2017; Demeter, Losonci \& Nagy, 2020). Both of these concepts add to the overall competitiveness of companies and demand new capabilities and attitudes e.g. high level of willingness to innovate and cooperate with stakeholders. Could these intensely researched concepts work together, support each other and provide a more sustainable future?

In our paper, we investigate the possible connection between digitalization and sustainability, but we narrow digitalization to the use of Information and Communication Technologies (ICT) in companies. In our opinion it is important to analyze the different green practices and their popularity for further policy and managerial implications as well.

The paper is structured as follows: in the "Introduction" we summarized the role of ICT in companies and its effect on the environment. Then we formulated our hypotheses and the way we analyze the topic in the "Focus of the research" section. In the "Materials and methods" section, we introduce the Hungarian Competitiveness Study and its extensive questionnaire we used to test our research questions, along with the exact methodology we chose. The next section summarizes the results of the analysis, while the discussion part presents our new results and their relevance for science and industry. The "Conclusions" sums up the most important results and discusses the limitations of the study and future research directions. Our results will be useful for practitioners and policymakers as well. In our opinion, it is important to analyze the different environmental performance indicators and their popularity for further policy and managerial implications.

\section{Literature review}

The next section consists of a short review of the ICT related literature, highlights the importance of sustainability in the business sector and links ICT to environmental performance.

Information and communication technology (ICT) has gone through intense development and spread over the past decades. According to Weber and Kaufman's definition (Weber \& Kaufmann, 2011, p. 684) ICT is understood "as technologies that support data and information processing, storage and analysis, as well as data and information transmission and communication, via the Internet and other means". In this means, we cannot imagine either our homes or workplaces without the presence of various ICT tools and numerous pieces of software are available to support our lives and work.

ICT technologies in business processes became indispensable in the digital era. ICT contribution to productivity and economic growth has been widely discussed (Ishida, 2015; Higón, Gholami \& Shirazi, 2017). ICT also takes the main role in the economy transformation and become a vital source of competitive advantage (Becker et al., 2009; Powell \& Dent-Micallef, 1997; Michalic \& Buhalis, 2013). Although Ollo-Lopez and Aramendía-Muneta (2011) discovered no relationship between ICT and company competitiveness, they found that advanced ICT favours innovation, launching new products and services and implementing new processes which can enhance firm competitiveness eventually.

The level of ICT development maturity can be described in several ways (Pham, 2010; Chesher \& Skok, 2000) based on the companies' policies towards ICT, the available hardware and software, and in connection with the users. There are also several indices to measure ICT development (e.g. Digital Opportunity Index and ICT Opportunity Index by International Telecommunication Union) on the country level and individual/household level as well.

About sustainability, we can agree that the greatest challenge of the $21^{\text {st }}$ century is to tackle climate change and set our society on a sustainable path. Since the first definitions of sustainable development in the 1980ies, a very slow transition has started in the business sector. As Bansal and Roth (2000) point out, environmental protection can be important for companies because of maintaining competitiveness, complying with legislation, and because of internal beliefs. Nowadays operating a company sustainably and responsibly is necessary in order to meet customer demand and be able to compete in the current business environment. Companies are expected to improve their environmental performance firstly because they have to comply with government regulations and in some cases, taxes are connected to emissions to the environment. Customers and business partners may also put them under pressure since customers want sustainable products and services, while investors want new business opportunities, and market development (Antoni \& Jie, 2012). According to the ISO14001 standard's definition, environmental performance means the "measurable results of an organization's management of its environmental aspects" (ISO14001). Corporate environmental performance and environmental performance indicators have very diversified literature. Measuring environmental performance has become increasingly popular as its strategic role was recognized: green management was proven to enhance the long-term competitiveness and economic performance (Rao \& Holt, 
2005 in Tuni, Rentizelas \& Duffy, 2018). The current methods for environmental performance evaluation are the measurement of environmental performance and evaluation of the conditions of material balance (Coelli, Lauwers \& Huylenbroeck, 2007 in Song, Fisher, Wang \& Cui, 2018), strategic environmental assessment (SEA) (Zhu \& Ru, 2008 in Song et al., 2018), ecological footprinting (Bagliani, Galli, Niccolucci \& Marchettini, 2008 in Song et al., 2018), cost-benefit analysis (Mouter, Annema \& Van Wee, 2013, in Song et al., 2018), data envelopment analysis and life cycle assessment methods (Song et al., 2018).

The following discussions show examples of the potential of ICT on the possible improvement of environmental performance. It is emphasized that ICT tools can enable organizational practices and processes that improve environmental and economic performance (Melville, 2010). Researchers found that IT improves the management of talent, which in turn enables execution of a more environmentally sustainable operations strategy and increase firm performance (Benitez-Amado, LlorensMontes \& Fernandez-Perez, 2015). In ASEAN countries, a relationship was found among ICT, economic growth and $\mathrm{CO}_{2}$ emission (Lee \& Brahmasrene, 2014). They proved that ICT has a significant positive effect on both.

We can see articles focusing on the environmental effects of ICT. Cai, Chen and Bose (2013) found a positive relationship between IT and environmental sustainability strategy in companies, and they also find this important from the competitiveness point of view. It was proved that IT supports the coordination of product design and manufacturing, and strengthen the effect of environmental practices (Gimenez, Sierra, Rodon \& Rodriguez, 2015). From another point of view, it was propounded that CSR reporting is a highly complex process and requires a large amount of data, which need to be stored, processed and analyzed (Watts, 2015). ICT can support transparent processes on a high level, with improved accuracy. Pekovic, Grolleau and Mzoughi (2018) analyzed the effects of environmental investments - including machinery, equipment to treat, measure, control or restrict pollution, which obviously need IT support - on the economic performance of firms, and they found that there is an optimal level of environmental investments which have a positive effect on net profit.

There are some papers that list the pro and con examples and highlight the controversial effects of ICT on environmental performance (Ishida, 2015; Yi \& Thomas, 2007). They state that ICT supports economic growth, social development and environmental protection, although computers contain parts that are toxic, and to produce semiconductor wafers manufacturers use a considerable amount of water and energy. Research compared on-line and offline book retailers and concluded that it cannot be decided which is more energy efficient (Matthews, Williams, Tagami \& Hendrickson 2002).

To sum up the controversial effects of ICT development from an environmental perspective, we can confirm that the spread of ICT tools and the increase of their capacity and performance enhance the need for energy, and a large amount of electronic waste pollutes the environment (Yi \& Thomas, 2007, Radu, 2016). On the other hand, improvement of ICT and consequently the increasing efficiency of the companies and/or production processes might save us energy, waste, pollution or workload (Radu, 2016).

According to Subburaj \& Kulkarni (2014), there are green or environmental ICT systems which can support environmentally sustainable business operations. These are hardware and software solutions that have a low environmental impact or contribute to reducing the environmental impact of an industry or society (Cecere, Corrocher, Gossart \& Ozman, 2014; Radu, 2016).

In the above-mentioned papers, environmental performance is usually captured by $\mathrm{CO}_{2}$ or other kinds of emission. We identified that as a gap since environmental performance should not be narrowed down to emission, it is a more complex phenomenon. Environmental performance of an organization is determined by several factors (Butti, Guarnaccia, Cosentino, Leonardi, Caruso et al., 2019; Gaviglio, Bertocchi \& Demartini 2017), e.g. management approach, input and output of material and energy, position and strength in the supply chain it operates in and so on. This is what we would like to focus our paper on. How can an extensive environmental performance measurement be supported by ICT?

\section{Focus of the research}

There is already a current discussion (Hilty, Lohmann \& Huang, 2011; Ollo-Lopez \& Aramendía-Muneta, 2011; Melville, 2010; Wang, Sanchez Rodriguez \& Evans, 2015; Evangelista, Santoro \& Thomas, 2018; Kayikci, 2018) on the use of digitalization and its effects on environmental performance, which we would like to contribute to. However, our viewpoint is different from the current articles, since we explored the relationship between the use of ICT and environmental performance and did not measure the effects of the two on each other. Our hypothesis is that a higher level of ICT development in a company results in improved environmental performance. "You can manage what you measure, and you manage what you care about", says Steve Howard in a Ted Talk about sustainability (Howard, 2013). Our starting point is that ICT enables companies to measure and manage data, which can give insight into their environmental performance. On the other hand, ICT-use requires organizational capabilities that support innovation, which is also a key element, that can further environmental sustainability within an organization (e.g. ecodesign, environmental management, process innovation). To analyze this hypothesis, we apply two models: one, which helps us to assess a company's ICT maturity and another one which interprets environmental performance in a complex manner, not only along with emissions. With the help of these models, we explore indepth how the different ICT development stages affect environmental performance.

One of the models applied, measures the maturity of ICT in a company. Since ICT has a great potential to 
transform a company's operations and has a key role in data collection and analysis (e. g. building corporate knowledge and sharing it within the firm) (Pham, 2010; Chesher \& Skok, 2000), it is not enough to report on what kind of hardware and software is used at the company. ICT has to be analyzed with a wider scope if it has a strategic role in the company, the types and the variety of tools, and the way they are used. For this reason, the ICT development was analyzed along four aspects suggested by Pham (2010): ICT policy, infrastructure, applications and human resource. ICT policy refers to written or unwritten rules, procedures and ways of doing business in an enterprise. Infrastructure covers the devices and services which help the company in storing, processing, communicating, and sharing information. Applications refer to the software which help to do business. Human resource issues deal with ICT literacy, skills and also innovation skills.

The sustainability-related analysis focuses on environmental sustainability based on the multidimensional environmental performance model suggested by Schultze and Trommer (2012). This model was chosen because the environmental performance of an organization is determined by different factors (Butti et al., 2019; Gaviglio et al., 2017), not exclusively by $\mathrm{CO}_{2}$ and other emissions which is widely used in the related literature (Lee \& Brahmasrene, 2014; Ishida, 2015; Wang et al., 2015). The Schultze-Trommer-model distinguishes operational and strategic factors influencing environmental performance, and on operational level, it separates performance indicators related to the inputs, the processes, the outputs and the outcome. This way this model is complex enough to get a picture of a company's environmental pursuit.

In the next chapter, we introduce the materials and methods we used to test Pham's and Schultze-Trommer's models.

\section{Materials and methods}

\section{Database}

The hypothesis will be explored by using statistical analyses. The database has been prepared by the Hungarian Competitiveness Research Centre (HCRC) which operates at Corvinus University of Budapest and surveys the companies' competitiveness in approximately every five years. The first Hungarian Competitiveness Survey was carried out in 1995 and since then, five others followed. We have to note that the questionnaire was originally made for assessing the companies' competitiveness form various dimensions. We selected questions from the questionnaire which were suitable for measuring the interdependency of the ICT development stage and environmental performance in our study. However, we have to note, that since the survey had a different original purpose, only a limited number of questions or variables were suitable for our aims. Although the database is from 2013 (HCRC, 2013), we have revealed many interesting connections between ICT development and environmental performance. The relevance of the topics is evergreen, but the technological environment of the recent years has brought substantial developments that indicate that it might be worth to continue the research in the future.

The questionnaire of the survey is almost 100 pages long and can be divided into four blocks. Within each block, chapters cover a wide range of management topics. The first block is dedicated to the CEO and the board, dealing with issues like the basic data about the firm, the internal and external environment, strategy, and management structure of the company. The CEO block also deals with human resources management and controlling topics. The second block is dedicated to the $\mathrm{CFO}$, reviewing the finances, investments and controlling issues. The third block targets the production (or service) managers, requesting data about the operations processes, the supporting hardware and software infrastructure, innovation, logistics and supply chain management and the environmental protection. The fourth block targets the sales or marketing directors, aiming to gather data about the general market position of the company, the long-term relationships, the marketing activity, its assessment and effectiveness. The questionnaire applied mainly multiplechoice or Likert-scale methods and open-ended questions, too. In our analysis, we used questions of the first (CEO) and the third, production blocks (see Table 1 and 2).

\section{Statistical methods}

We applied cluster analysis to separate companies in the sample which are well-developed from ICT point of view, and which are not. After having the clusters, we describe their state of ICT development and give a description about their environmental performance, the green practices and environmental management tools they apply. The logic of the analysis can be seen in Figure 1.

\section{Logic of the analysis}

Figure 1.

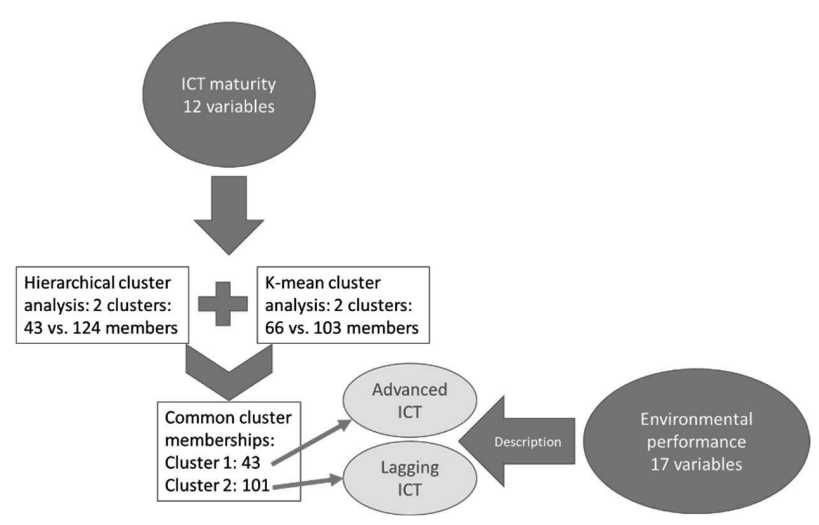

Source: own compilation

We selected 12 questions in accordance with the ICT maturity model (Pham, 2010), which we think reveals if the respondent company is developed in ICT or not. During the selection, we had to consider the variables and scales and standardize them, where necessary. It was also a problem that in case of many questions so many answers were missing that it distorted the results or made 
it impossible to interpret. Consequently, we had to exclude them. Table 1 and 2 show the final questions used for the analysis.

Table 1.

\section{Selected questions to assess ICT maturity} (own edition)

\begin{tabular}{|c|c|c|}
\hline $\begin{array}{c}\text { Maturity } \\
\text { dimensions } \\
\text { (Pham, 2010) } \\
\end{array}$ & Questions & Answer options \\
\hline ICT Policy & $\begin{array}{l}\text { Is there a written } \\
\text { ICT strategy at your } \\
\text { company? }\end{array}$ & Yes/No \\
\hline \multirow[t]{4}{*}{ Infrastructure } & $\begin{array}{l}\text { Do you use server } \\
\text { virtualization in your } \\
\text { company? }\end{array}$ & \multirow{4}{*}{$\begin{array}{l}\text { 4-point scale, } \\
\text { where } \\
\text { 1: we use it } \\
\text { 2: it is under } \\
\text { implementation } \\
\text { 3: we plan to } \\
\text { implement } \\
\text { within } 2 \text { years } \\
\text { 4: we are not } \\
\text { planning at all }\end{array}$} \\
\hline & $\begin{array}{l}\text { Do you use cloud in your } \\
\text { company? }\end{array}$ & \\
\hline & $\begin{array}{l}\text { Do you use open source } \\
\text { system(s) in your } \\
\text { company? }\end{array}$ & \\
\hline & $\begin{array}{l}\text { Do you use mobile } \\
\text { phones and/or tablets in } \\
\text { your company? }\end{array}$ & \\
\hline \multirow[t]{4}{*}{ Applications } & $\begin{array}{l}\text { Do you use ERP system } \\
\text { in your company? }\end{array}$ & \multirow{4}{*}{$\begin{array}{l}\text { 4-point scale, } \\
\text { where } \\
\text { 1: we use it } \\
\text { 2: it is under } \\
\text { implementation } \\
\text { 3: we plan to } \\
\text { implement } \\
\text { within } 2 \text { years } \\
\text { 4: we are not } \\
\text { planning at all }\end{array}$} \\
\hline & $\begin{array}{l}\text { Do you use Business } \\
\text { Intelligence system in } \\
\text { your company? }\end{array}$ & \\
\hline & $\begin{array}{l}\text { Do you use Expert } \\
\text { system in your company? }\end{array}$ & \\
\hline & $\begin{array}{l}\text { Do you use workflow } \\
\text { / groupware in your } \\
\text { company? }\end{array}$ & \\
\hline \multirow[t]{3}{*}{$H R$} & $\begin{array}{l}\text { The output of the } \\
\text { company contains high } \\
\text { level of innovation }\end{array}$ & \multirow{3}{*}{$\begin{array}{l}\text { 5-point scale, } \\
\text { where } \\
1: \text { the statement } \\
\text { is not valid for } \\
\text { the company } \\
\text { at all } \\
3: \text { the statement } \\
\text { is valid more or } \\
\text { less } \\
5: \text { the statement } \\
\text { is valid in every } \\
\text { case }\end{array}$} \\
\hline & $\begin{array}{l}\text { To plan and design } \\
\text { our products we use } \\
\text { innovative IT tools. }\end{array}$ & \\
\hline & $\begin{array}{l}\text { To manufacture our } \\
\text { products we use } \\
\text { innovative IT tools. }\end{array}$ & \\
\hline
\end{tabular}

Source: own compilation

The ICT policy was measured by whether there is a written IT strategy at the company or not. Infrastructure was captured by innovative solutions like cloud and server virtualization, which means, that companies hire data storage equipment and space at server operators that have huge server parks with different performance characteristics and can offer customized portfolio, fitting to the actual needs. Application of open-source systems allows companies to have updates frequently and if they have their own ability, to customize the software on their own. It is even more common at companies which offer user-friendly mobile phone or tablet applications. The spread of these devices within a company might also indicate the development stage of ICT.
The most basic selected ICT application was the ERP system since the use of this is essential to have processes under control within a company and be able to analyze and give structured reports on them. ERP is also important because many other IT tools and solution are built on it and interconnected with it. Using workflow and groupware indicate that a company has well-defined administration, problem-solving routes, the tasks are allocated to workers clearly. On the way of digitalization, the most important thing is to start collecting data on core processes and to analyze them. Having rapidly growing databases at companies increased the need for alternative data storage systems, which can substitute and disencumber corporate data warehouses and servers. The data also have to be analyzed and used in decision making properly. Application of business intelligence and expert systems are developed solutions already. Business intelligence assures that the data for different business areas are analyzed and reported. Expert systems use algorithms, maybe artificial intelligence to interpret the information gathered from the data and help top management in making right decisions. The latter question mainly supports the technological background of developed ICT activity in a company.

The model considers human resource issues widely, including ICT literacy, ICT skills and innovation skills also. Product/service innovation is typically a task requiring creativity and human input, not suitable for automation. We consider innovation strongly connected to people and the use of IT tools represents the personmachine symbiosis, which can be a determinant of ICT maturity as well. Accordingly, we investigated the innovation content of the companies' products or services, whether they support the design and planning of products and services by IT and how much the manufacturing process of the products/services is supported by IT. We used the latter questions to run cluster analyses which will be introduced in Analysis chapter.

\section{Environmental performance}

As a second step, we selected environmental sustainability related questions from the HCRC and assumed that if the answers are positive, the green practice is present at the company, so we considered the answers as indicators. For example, if a company answered that they did dedicate resources to the reduction of water use in the production processes we assumed that they have some green initiatives implemented for this goal, which we counted as an environmental indicator used.

The description of the clusters from an environmental performance point of view is based on the multidimensional environmental performance model suggested by Schultze and Trommer (2012). The recent literature and other, nonacademic sources almost exclusively use the greenhouse gas emissions and $\mathrm{CO}_{2}$ emissions (Hilty et al., 2011; Wang et al., 2015; Konar \& Cohen, 2001) to determine environmental performance. We chose the model described by Schultze and Trommer (2012) because in our opinion it is important to draw attention to the fact, that environmental performance of an organization 
is determined by several factors, not exclusively by emissions. To capture the environmental performance indicators of the model, we selected 17 questions from the HCRC questionnaire, as it can be seen in Table 2 .

Table 2.

The questions used in the HCRC survey according to multidimensional environmental performance model suggested by Schultze \& Trommer (2012)

\begin{tabular}{|c|c|c|c|}
\hline & $\begin{array}{l}\text { Environmen- } \\
\text { tal performan- } \\
\text { ce indicators }\end{array}$ & Questions & $\begin{array}{l}\text { Answer } \\
\text { options }\end{array}$ \\
\hline \multirow[t]{10}{*}{$\begin{array}{l}\text { I. Operational } \\
\text { indicators }\end{array}$} & & & \\
\hline & \multicolumn{3}{|c|}{ I./A Input oriented indicators } \\
\hline & Energy & $\begin{array}{l}\text { Did the company } \\
\text { dedicate } \\
\text { resources to } \\
\text { the reduction } \\
\text { of energy use } \\
\text { in production } \\
\text { processes? }\end{array}$ & $\mathrm{Yes} / \mathrm{No}$ \\
\hline & Water & $\begin{array}{l}\text { Did the company } \\
\text { dedicate } \\
\text { resources to } \\
\text { the reduction } \\
\text { of water use } \\
\text { in production } \\
\text { processes? } \\
\end{array}$ & Yes/No \\
\hline & Material use & $\begin{array}{l}\text { Did the company } \\
\text { dedicate } \\
\text { resources to } \\
\text { the reduction of } \\
\text { material use of } \\
\text { production? }\end{array}$ & Yes/No \\
\hline & \multicolumn{3}{|c|}{ I./B Process indicators } \\
\hline & Recycling & $\begin{array}{l}\text { Did the company } \\
\text { dedicate } \\
\text { resources to the } \\
\text { reuse of waste } \\
\text { materials within } \\
\text { the company } \\
\text { operations? } \\
\end{array}$ & Yes/No \\
\hline & $\begin{array}{l}\text { Reuse of } \\
\text { materials }\end{array}$ & $\begin{array}{l}\text { Did the company } \\
\text { dedicate } \\
\text { resources to } \\
\text { the reuse of } \\
\text { products? }\end{array}$ & Yes/No \\
\hline & $\begin{array}{l}\text { Elimination } \\
\text { of hazardous } \\
\text { materials }\end{array}$ & $\begin{array}{l}\text { Did the company } \\
\text { dedicate } \\
\text { resources to the } \\
\text { elimination of } \\
\text { hazardous input } \\
\text { materials? }\end{array}$ & $\mathrm{Yes} / \mathrm{No}$ \\
\hline & $\begin{array}{l}\text { Packaging } \\
\text { recycling }\end{array}$ & $\begin{array}{l}\text { Did the company } \\
\text { dedicate } \\
\text { resources to } \\
\text { the recycling of } \\
\text { packaging? }\end{array}$ & Yes/No \\
\hline
\end{tabular}

\begin{tabular}{|c|c|c|c|}
\hline & $\begin{array}{l}\text { Reduction of } \\
\text { packaging }\end{array}$ & $\begin{array}{l}\text { Did the company } \\
\text { dedicate } \\
\text { resources to } \\
\text { the reduction } \\
\text { of packaging } \\
\text { materials for } \\
\text { product units? }\end{array}$ & Yes/No \\
\hline & $\begin{array}{l}\text { Environmental } \\
\text { criteria for } \\
\text { suppliers/ } \\
\text { supplier } \\
\text { evaluation }\end{array}$ & $\begin{array}{l}\text { Does the } \\
\text { company } \\
\text { have written } \\
\text { environmental } \\
\text { criteria set for } \\
\text { suppliers? }\end{array}$ & Yes/No \\
\hline & I./C Output orie & nted indicators & \\
\hline & $\begin{array}{l}\text { Environmental } \\
\text { performance } \\
\text { measurement } \\
\text { system }\end{array}$ & $\begin{array}{l}\text { Is environmental } \\
\text { performance } \\
\text { measurement } \\
\text { present by the } \\
\text { company? }\end{array}$ & Yes/No \\
\hline & $\begin{array}{l}\text { Environmental } \\
\text { accounting }\end{array}$ & $\begin{array}{l}\text { Is environmental } \\
\text { accounting } \\
\text { system present } \\
\text { by the company? }\end{array}$ & Yes/No \\
\hline & I./D Outcome o & iented indicators & \\
\hline & $\begin{array}{l}\text { Training of } \\
\text { employees }\end{array}$ & $\begin{array}{l}\text { Is an } \\
\text { environmental } \\
\text { training program } \\
\text { in place for } \\
\text { employees? }\end{array}$ & Yes/No \\
\hline & $\begin{array}{l}\text { Environment- } \\
\text { related criteria } \\
\text { in employee } \\
\text { performance } \\
\text { measurement }\end{array}$ & $\begin{array}{l}\text { Is there } \\
\text { environment- } \\
\text { related criteria } \\
\text { present in } \\
\text { employer } \\
\text { evaluation? }\end{array}$ & Yes/No \\
\hline & $\begin{array}{l}\text { Environmental } \\
\text { auditing }\end{array}$ & $\begin{array}{l}\text { Is there regular } \\
\text { auditing of the } \\
\text { environmental } \\
\text { management } \\
\text { practices? }\end{array}$ & Yes/No \\
\hline $\begin{array}{l}\text { II. Strategic } \\
\text { indicators }\end{array}$ & & & \\
\hline & $\begin{array}{l}\text { Manager/ } \\
\text { department } \\
\text { responsible for } \\
\text { environmental } \\
\text { issues } \\
\text { within the } \\
\text { organizational }\end{array}$ & $\begin{array}{l}\text { Is at least middle } \\
\text { managerial level } \\
\text { responsible for } \\
\text { environmental } \\
\text { issues within the } \\
\text { organization? }\end{array}$ & Yes/No \\
\hline & $\begin{array}{l}\text { Environmental } \\
\text { policy, goal } \\
\text { setting }\end{array}$ & $\begin{array}{l}\text { Does the } \\
\text { organization } \\
\text { have a written } \\
\text { environmental } \\
\text { policy? }\end{array}$ & Yes/No \\
\hline & $\begin{array}{l}\text { Sustainability } \\
\text { reporting }\end{array}$ & $\begin{array}{l}\text { Does the } \\
\text { organization } \\
\text { have a publicly } \\
\text { available } \\
\text { environmental } \\
\text { or sustainability } \\
\text { report? }\end{array}$ & Yes/No \\
\hline
\end{tabular}

Source: own compilation 
Many questions of the original questionnaire refer to the resources dedicated to certain "green" activities (for example: Did the company dedicate resources to the reduction of energy use in production processes?) and these are yes/no questions. We are aware of the limitation that this type of questions holds: the final result of dedicating resources to a certain activity might not turn out as expected (in this case, a better environmental performance).

The operational block includes input-oriented indicators in form of energy- and water use, along with material use. This block also includes environmental sustainability indicators of service and production processes, which refer to the resources dedicated to recycling, reuse of materials, elimination of hazardous materials, reduction of packaging, or packaging recycling. We also considered environmental sustainabilitybased supplier evaluation as a process indicator. Output oriented indicators in this model include environmental performance measurement system used by the company and also environmental accounting.

Several questions were also selected from the HCRC survey for the outcome-oriented indicator group as well, which include regular auditing of environmental management system, training of employees in terms of environmental protection and environment-based employee evaluation practices.

Strategic indicators include if there is at least a middle managerial level is responsible for environmental issues within the organization, if the organization has written environmental policy and if it publishes environmental or sustainability reports. This is important, since in this framework, environmental performance refers to operational indicators and corporate behaviour in form of strategic indicators too thus gives a reliable and valid picture of a company's attitude towards environmental sustainability along 17 dimensions.

The 17 dimensions of environmental performance are used for identify the characteristics of clusters we produce along with the ICT development in Analysis chapter.

\section{Analysis and results}

In the following section, we introduce the analyses we have carried out. The accidental multicollinearity of the variables (see Table 3 and 4) allocated to Pham's model was tested by Pearson's correlation coefficient. In only two cases was $r$ higher than 0.7 while all other correlations are acceptable (Sajtos \& Mitev, 2007) so the variables are suitable for analysis. After we made sure that the selected questions are suitable for analysis, two cluster analyses were run. By using SPSS 25 statistics program, first, a hierarchical cluster analysis was carried out (betweengroups linkage method) which produced two clusters, with a population of 43 and 124 companies. Hierarchical methods can be used easily and can provide reliable results on a large sample (Sajtos \& Mitev, 2007). To test the results of the hierarchical cluster analysis, we ran a K-mean cluster analysis, too. We obtained two clusters again with a population of 66 and 103 companies, and the membership of the clusters almost overlap, 17 companies changed place between clusters. As ultimate results, we accepted the cluster memberships where the two methods gave the same result. This way, the first cluster contains 43, the second 101 companies.

The difference between Cluster 1 and 2 in ICT use is revealed in Table 3. In order to have reliable results, crosstable analysis was run to compare the results of the two clusters, and the difference was tested by Cramer's V on a $5 \%$ significance level. Differences of the clusters' results proved statistically significant. Based on these differences, we named Cluster 1 as Advanced in ICT and Cluster 2 as Lagging in ICT.

Table 3.

Results of clusters' ICT performance (own edition)

\begin{tabular}{|c|c|c|c|c|}
\hline $\begin{array}{c}\text { Maturity } \\
\text { dimension }\end{array}$ & Questions & $\begin{array}{c}\text { Cluster } 1 \\
\text { Advanced } \\
\text { ICT }\end{array}$ & $\begin{array}{c}\text { Cluster } 2 \\
\text { Lagging } \\
\text { ICT }\end{array}$ & Sig. \\
\hline ICT Policy & $\begin{array}{l}\text { Written ICT } \\
\text { strategy }\end{array}$ & $70 \%$ & $36 \%$ & .000 \\
\hline \multirow[t]{4}{*}{$\begin{array}{l}\text { Infrastruc- } \\
\text { ture }\end{array}$} & $\begin{array}{l}\text { Server virtua- } \\
\text { lization }\end{array}$ & $53 \%$ & $11 \%$ & .000 \\
\hline & Cloud & $27 \%$ & $12 \%$ & .026 \\
\hline & $\begin{array}{l}\text { Open source } \\
\text { system(s) }\end{array}$ & $58 \%$ & $15 \%$ & .000 \\
\hline & $\begin{array}{l}\text { Mobile pho- } \\
\text { nes and/or } \\
\text { tablets }\end{array}$ & $79 \%$ & $33 \%$ & .000 \\
\hline \multirow{4}{*}{$\begin{array}{l}\text { Applica- } \\
\text { tions }\end{array}$} & ERP system & $65 \%$ & $17.5 \%$ & .000 \\
\hline & $\begin{array}{l}\text { Business } \\
\text { Intelligence } \\
\text { system }\end{array}$ & $93 \%$ & $7 \%$ & .000 \\
\hline & $\begin{array}{l}\text { Expert sys- } \\
\text { tem }\end{array}$ & $72 \%$ & $0 \%$ & .000 \\
\hline & $\begin{array}{l}\text { Workflow / } \\
\text { groupware }\end{array}$ & $65 \%$ & $7 \%$ & .000 \\
\hline
\end{tabular}

Note: \% means that this \% of companies in the given cluster uses a method or a tool

Source: own compilation

Regarding ICT policy, almost double of Cluster 1 companies have a written ICT strategy than Cluster 2 companies. Infrastructure dimension suggests that ICT capabilities are better in Cluster 1 firms since they can develop open-source software on their own. It also seems that firms trust servers more - even virtual onesto store their data, than cloud solutions. The share of mobile phone/tablet applications are also more frequent in Advanced ICT cluster, which requires hardware and software engineering capabilities as well. The impressive difference can be seen between the two clusters in terms of the applications. Software that can support processes, help to make them more transparent and optimized are applied by Advanced ICT cluster extensively, while in Cluster 2 their share is very low. To complete the human resources dimension with the context of innovation we used ANOVA F-probe to compare the cluster means. Cluster 1 outshines 
Cluster 2 in all aspects, as it can be seen in Table 4. Results suggest that innovativeness and IT support is more typical in Cluster 1 than in Cluster 2.

Table 4.

Compare of means with ANOVA to measure human resources dimension with the context of innovation

\begin{tabular}{|l|c|c|c|}
\hline & $\begin{array}{c}\text { Cluster 1. } \\
\text { Advanced } \\
\text { ICT }\end{array}$ & $\begin{array}{c}\text { Cluster 2. } \\
\text { Lagging } \\
\text { ICT }\end{array}$ & Sig. \\
\hline Innovative product, service & 3.21 & 2.15 & 0.000 \\
\hline $\begin{array}{l}\text { IT-aided product/service } \\
\text { design and planning }\end{array}$ & 3.26 & 2.12 & 0.000 \\
\hline IT support of manufacturing & 3.28 & 2.28 & 0.000 \\
\hline
\end{tabular}

Note: respondents assessed if they have the above technology on a 5-point Likert-scale, where 1 meant they do not use it, 5 meant they use it extensively

Source: own compilation

We also analyzed the general characteristics of the clusters and got significantly different data. Results say that advanced ICT firms mainly operate in the processing industry, most of them employ more than 100 people and according to the turnover data, third of them are large, almost two-third are middle-size companies. Most of the lagging ICT firms have less than 100 employees, the share of SME-s is more than 80 per cent. The firms in this cluster mainly operate in the processing industry and commerce.

The focus of our analysis was to show, how the two clusters differ in environmental performance. Results of the clusters were compared by SPSS 25 again, applying $5 \%$ significance level and reliability was tested by Phi and Cramer's V. Not all the results are statistically significant (11/17 are), but they provide possibilities for discussion (Table 5).

Table 5.

Results of clusters' environmental performance

\begin{tabular}{|l|l|l|l|}
\hline $\begin{array}{c}\text { Environmental performance } \\
\text { indicators (Schultze and } \\
\text { Trommer, 2012) }\end{array}$ & $\begin{array}{c}\text { Cluster 1 } \\
\text { Advanced } \\
\text { ICT }\end{array}$ & $\begin{array}{c}\text { Cluster 2 } \\
\text { Lagging } \\
\text { ICT }\end{array}$ & Sig. \\
\hline I. Operational indicators & \multicolumn{2}{|l|}{} \\
\hline I/A Input oriented indicators & $97 \%$ & $82 \%$ & .044 \\
\hline Energy & $77 \%$ & $56 \%$ & .052 \\
\hline Water & $85 \%$ & $67 \%$ & .082 \\
\hline Material use & $75 \%$ & $46 \%$ & .01 \\
\hline I/B Process indicators & $82 \%$ & $31 \%$ & .000 \\
\hline Recycling & $86 \%$ & $51 \%$ & .002 \\
\hline Reuse of materials & $64 \%$ & $39 \%$ & .055 \\
\hline $\begin{array}{l}\text { Elimination of hazardous } \\
\text { materials }\end{array}$ & $72 \%$ & $45 \%$ & .015 \\
\hline Packaging recycling & $60 \%$ & $34 \%$ & .004 \\
\hline Reduction of packaging & & & \\
\hline $\begin{array}{l}\text { Environmental criteria for } \\
\text { suppliers/supplier evaluation }\end{array}$ &
\end{tabular}

\begin{tabular}{|l|l|l|l|}
\hline I/C Output oriented indicators \\
\hline $\begin{array}{l}\text { Environmental performance } \\
\text { measurement system }\end{array}$ & $50 \%$ & $24 \%$ & .013 \\
\hline Environmental accounting & $51 \%$ & $20 \%$ & .000 \\
\hline $\begin{array}{l}\text { I/D Outcome oriented indi- } \\
\text { cators }\end{array}$ & $54 \%$ & $30 \%$ & .009 \\
\hline Training of employees & $28 \%$ & $22 \%$ & .445 \\
\hline $\begin{array}{l}\text { Environment-related criteria } \\
\text { in employee performance } \\
\text { measurement }\end{array}$ & $56 \%$ & $27 \%$ & .002 \\
\hline Environmental auditing & $70 \%$ & $56 \%$ & .004 \\
\hline \begin{tabular}{l} 
II. Strategic indicators \\
\hline $\begin{array}{l}\text { Manager/department respon- } \\
\text { sible for environmental issues } \\
\text { within the organizational }\end{array}$
\end{tabular} & $79 \%$ & $30 \%$ & .000 \\
\hline $\begin{array}{l}\text { Environmental policy, goal } \\
\text { setting }\end{array}$ & $34 \%$ & $19 \%$ & .067 \\
\hline Sustainability reporting &
\end{tabular}

Note: \% means that this \% of companies in the given cluster uses a method Source: own compilation

Regarding input and process-oriented indicators, questions measured whether the companies spent on different projects to reduce their environmental footprint. Both clusters made some efforts: $97 \%$ of Cluster 1 and $82 \%$ of Cluster 2 companies reduced the energy consumption of manufacturing (service) process, which is a statistically significant difference (5\% significance level) but shows efforts of both clusters towards economically advantageous green initiatives. Analyzing the outputoriented indicators $(\mathrm{I} / \mathrm{C}), 50 \%$ of the Cluster 1 companies have environmental performance measurement system in place, while only $24 \%$ of those in Cluster 2 . Cluster 1 and 2 companies show a significant difference in environmental accounting as well by $50 \%$ and $21 \%$ of the companies using this environmental management tool. Among the outcome-oriented indicators (I/D) two questions proved to be statistically significant: $54 \%$ of Cluster 1 companies offer environmental training to employees and $56 \%$ of Cluster 1 firms use environmental auditing. Finally, strategic indicators (II.) show that a large share $(79 \%)$ of advanced IT cluster companies have written environmental policy while in Cluster 2 only $30 \%$ sets formal targets.

\section{Discussion}

In the paper, we analyzed the level of ICT use and the environmental performance of companies based on two theoretical models. Some previous scientific papers already connected ICT and environmental sustainability before (Ishida, 2015; Ollo-Lopez \& Aramendía-Muneta, 2011; Yi \& Thomas, 2007; Gimenez et al., 2015), but either they used a technology-oriented ICT approach (Becker et al., 2009; Weber \& Kauffman, 2011; Gimenez et al., 2015) or interpreted sustainability only through output/processbased indicators (Ishida, 2015; Higón et al., 2017; Gimenez et al., 2015). 
Our contribution is that we discuss both ICT maturity and environmental performance indicators from a broad perspective. In ICT literature, we found that papers interpret ICT development based mainly on the technological background (Weber \& Kaufmann, 2011; Ishida, 2015), but the model we applied pointed out that ICT has an important role in organization and innovationrelated aspects as well (Ollo-Lopez \& Aramendía-Muneta, 2011; Pham, 2010). The choice of the multidimensional environmental performance model was even more important. In the literature, we found mainly process (material and energy consumption) (Yi \& Thomas, 2007; Higón et al., 2017) and output (GHG and/or $\mathrm{CO}_{2}$ emission) oriented indicators (Lee \& Brahmasrene, 2014), although there are many other indicators - input, outcome and strategy - which are also important in connection with a company's environmental performance (Schultze \& Trommer, 2012).

The cluster analysis based on the variables seen in Table 3 and 4 produced us two clusters being substantially different from the ICT development point of view (See Table 3 and 4). The clusters differ not only in the aspects we have used for cluster analysis, but in some other respects. We found evidence for the statement of Ollo-Lopez \& Aramendía-Muneta (2011) about the positive effects of ICT on new product development, since advanced ICT companies were able to launch new products and services to the market three times more than lagging ICT firms. The experiences of Benitez-Amado et al. (2015) on the relationship between ICT and knowledge management was also proved, when we found that $53 \%$ of advanced ICT companies were able to renew the knowledge management system in the company, while only $14 \%$ in the lagging cluster did so.

Regarding the environmental performance differences of the clusters, we were not able to evince any controversial effect of ICT use on the environment as $\mathrm{Yi}$ and Thomas stated (2007), but we can say that advanced ICT helps companies to gather more data on the consumption of resources and it can be a basis of optimization. According to our study, there is a statistical connection between the level of ICT use and environmental performance and we have some promising results, as advanced ICT companies are ahead of the lagging group in many environmental practices as it is shown in Table 5. But this study was not able to prove if the statistical connection is a casual relationship, it requires further investigation. What we revealed is that advanced ICT companies use various methods to gather (ERP, BI), store (server virtualization and cloud) and process data (expert system, BI, workflow), and it results in a significantly better application of environmental accounting and environmental performance measurement system. This latter finding exceeds the ascertainment of Watts (2015) who proved the importance of ICT in CSR reporting.

By using the environmental performance model of Schultze \& Trommer (2012), we could compare the clusters' environmental performance in detail, as it was presented in Table 5. We concluded that "conscious" environmental performance management could not be carried out without the transparent operations in the company, which can be assured by sophisticated ICT solutions. Input use (water, energy, material) can be controlled by the big amount of data being collected, stored, and processed in the IT systems. Our results say that the Cluster 1 companies using ICT on a more advanced level have significantly better environmental performance in 11 out of 17 dimensions. The results correspond with the results of Melville (2010) and Gimenez et al. (2015) who emphasize that ICT tools can enable organizational practices and processes that improve environmental and economic performance. We also found that it is worth to interpret environmental performance in a wider sense, and add input, outcome and strategic dimensions to process and output-oriented indicators (Schultze \& Trommer, 2012; Butti et al., 2019; Gaviglio et al., 2017). Strategic indicators are quite important, environmental protection needs to be a strategic issue within a company (BenitezAmado et al., 2015). We found that strategic viewpoint is quite strong in advanced ICT companies since a third of them produce sustainability reports. Advanced ICT companies performed better in all aspects, and the difference was outstanding (and significant) in case of almost all strategic indicators, as well as in the most frequently used output and process-oriented indicators. The ICT maturity of the companies can play a great role in supporting the environmental sustainability-related data collection and processing especially in case of operational indicators.

As a summary, we can conclude that our original assumption - the higher level of ICT development in a company results in increasing environmental performance - is supported by the results, and it is worthy of further research.

\section{Conclusions}

The topic of sustainability and digitalization are among the most important and most researched topics nowadays. We used an ICT maturity model (Pham, 2010) and an environmental performance model (Schultze \& Trommer, 2012) and filled them with analyzable indicators from the HCRC study in each dimension. This way, we made a dual theoretical contribution: on one hand, we tested two models and on the other hand, we successfully connected the concept of environmental performance to ICT maturity.

With the cluster analysis we differentiated two groups of companies with significantly different ICT capabilities. We compared the environmental performance and the steps companies made towards improving environmental performance in case of the two clusters, and found significant differences, too.

The different behaviour of the representative variables of the environmental performance in the two clusters allows us to describe these behaviours in-depth and to point out the intuition of a possible relationship which is worthy of further analysis in the future. The 
environmental performance of advanced ICT companies can be subject of further in-depth analyses, to discover the type of additional effects on companies' overall performance. Another research project can be about the motivating factors of furthering the connected use of the two concepts to increase more competitiveness.

Our research has limitations. The database we used was prepared for different purposes, we were only able to use secondary data of a questionnaire which was already polled. It was difficult to find questions suitable to measure the different dimensions. Since we have promising results, it would be a good further study to edit a questionnaire exclusively to discover the probable casual relationship of ICT, digitalization, environmental performance and sustainability. Another limitation is the size and geographical coverage of the sample. The original sample contained 300 companies, but due to exclusions, only 144 remained and have been classified into advanced ICT cluster (43 companies) and lagging ICT cluster (101 companies). These cluster sizes, since they are not even representative, limit the general validity of our conclusions. The sample was collected in Hungary, and probably we could have different results if we analyze a more developed country or a cross-country sample. The result helped us to reveal interesting new research ideas described above which we intend to work with in the future.

The results can be useful for professionals since it shows that in the case of the companies that are advanced in ICT it is worth to make analyses of environmental performance. These companies probably have all the data necessary to monitor and evaluate their environmental performance, and it might help to make their operations more transparent and consequently, effective. Transparency may support convincing investors, stakeholders and customers, not to speak about a good reputation and corporate brand.

\section{References}

Antoni, D., \& Jie, F. (2012). The relationship between IT capability and organizational environment performance: A conceptual framework. In 3rd Annual international Conference on Infocomm Technologies in Competitives Strategies (ICT 2012) (pp. 47 - 53). Bali.

Bansal, P., \& Roth, K. (2000). Why companies go green: A model of ecological responsiveness. Academy of Management Journal, 43(4), 717-736.

https://doi.org/ 10.5465/1556363

Becker, J., Knackstedt, R., \& Pöppelbuß, J. (2009) Developing maturity models for IT management. Business and Information Systems Engineering, 1(3), 213-222.

https://doi.org/10.1007/s12599-009-0044-5

Benitez-Amado, J., Llorens-Montes, F. J., \& FernandezPerez, V. (2015) IT impact on talent management and operational environmental sustainability. Information Technology and Management, 16(3), 207-220. https://doi.org/10.1007/s10799-015-0226-4
Butti Al Shamsi, K., Guarnaccia, P., Cosentino, S. L., Leonardi, C., Caruso, P., Stella, G., \& Timpanaro, G. (2019). Analysis of Relationships and Sustainability Performance in Organic Agriculture in the United Arab Emirates and Sicily (Italy). Resources, 8(1), 39. https://doi.org/10.3390/resources8010039

Cai, S., Chen, X., \& Bose, I. (2013). Exploring the role of IT for environmental sustainability in China: An empirical analysis. International Journal of Production Economics, 146(2), 491-500. https://doi.org/10.1016/j.ijpe.2013.01.030

Cecere, G., Corrocher, N., Gossart, C., \& Ozman, M. (2014). Technological pervasiveness and variety of innovators in Green ICT: A patent-based analysis. Research Policy, 43(10), 1827-1839. https://doi.org/10.1016/j.respol.2014.06.004

Chesher, M., \& Skok, W. (2000). Roadmap for successful information technology transfer for small businesses. In Proceedings of the 2000 ACM SIGCPR conference on Computer personnel research, (pp. 16-22). New York: Association for Computing Machinery.

Demeter, K., Losonci, D., \& Nagy, J. (2020). Road to digital manufacturing-a longitudinal case-based analysis. Journal of Manufacturing Technology Management, Vol. ahead-of-print, No. ahead-of-print. https://doi.org/10.1108/JMTM-06-2019-0226

Eisenhardt, K. M., \& Martin, J. A. (2000). Dynamic capabilities: what are they? Strategic Management Journal, 21(10), 1105-1121. Retrieved from https:// www.jstor.org/stable/3094429

Evangelista, P., Santoro, L., \& Thomas, A. (2018). Environmental sustainability in third-party logistics service providers: A systematic literature review from 2000-2016. Sustainability, 10(5), 1627. https://doi.org/10.3390/su10051627

Gaviglio, A., Bertocchi, M., \& Demartini, E. (2017). A tool for the sustainability assessment of farms: selection, adaptation and use of indicators for an Italian case study. Resources, 6(4), 60. https://doi.org/10.3390/resources6040060

Gimenez, C., Sierra, V., Rodon, J., \& Rodriguez, J. A. (2015). The role of information technology in the environmental performance of the firm: The interaction effect between information technology and environmental practices on environmental performance. Academia Revista Latinoamericana de Administración, 28(2), 273-291. https://doi.org/10.1108/ARLA-08-2014-0113

Higón, D. A., Gholami, R., \& Shirazi, F. (2017). ICT and environmental sustainability: A global perspective. Telematics and Informatics, 34(4), 85-95. https://doi.org/10.1016/j.tele.2017.01.001

Hilty, L.M., Lohmann, W., \& Huang, E. M. (2011). Sustainability and ICT - An overview of the field. Politeia, 27(104), 13-28. https://doi.org/10.5167/uzh-55640

Howard, S. (2013). Let's go all in on selling sustainability. Ted Talk. Retrieved from https://www.youtube.com/ watch?v=buH_vs7LFzw 
Hungarian Competitiveness Research Centre (2013). Retrieved from https://www.uni-corvinus.hu/mainpage/research/research-centres/competitivenessresearch-centre/about/?lang=en

Ishida, H. (2015). The effect of ICT development on economic growth and energy consumption in Japan. Telematics and Informatics, 32(1), 79-88. https://doi.org/10.1016/j.tele.2014.04.003

ISO (2015). ISO 14001:2015. Terms and definitions Environmental performance. Retrieved from https:// committee.iso.org/files/live/sites/tc207sc1/files/ Terms $\% 20$ and $\% 20$ definitions $\% 20 \mathrm{in} \% 20$ ISO $\% 20$ 14001 2015\%20-\%20where $\% 20$ did $\% 20$ they $\% 20$ originate $\% 20$ from.pdf

Kayikci, Y. (2018). Sustainability impact of digitization in logistics. Procedia Manufacturing, 21, 782-789. https://doi.org/10.1016/j.promfg.2018.02.184

Konar, S., \& Cohen, M. A. (2001). Does the market value environmental performance? Review of Economics and Statistics, 83(2), 281-289. https://doi.org/10.1162/00346530151143815

Kraus S., Rehman S., \& García F.J.S. (2020). Corporate social responsibility and environmental performance: The mediating role of environmental strategy and green innovation, Technological Forecasting and Social Change, 160,120262. https://doi.org/10.1016/j.techfore.2020.120262

Lee, J. W., \& Brahmasrene, T. (2014). ICT, $\mathrm{CO}_{2}$ emissions and economic growth: Evidence from a panel of ASEAN. Global Economic Review, 43(2), 93-109. https://doi.org/10.1080/1226508X.2014.917803

Lenka, S., Parida, V., \& Wincent, J. (2017). Digitalization capabilities as enablers of value co-creation in servitizing firms. Psychology and Marketing, 34(1), 92-100.

https://doi.org/10.1002/mar.20975

Matthews, H. S., Williams, E., Tagami, T., \& Hendrickson, C. T. (2002). Energy implications of online book retailing in the United States and Japan. Environmental Impact Assessment Review, 22(5), 493-507.

https://doi.org/10.1016/S0195-9255(02)00024-0

Melville, N.P. (2010). Information systems innovation for environmental sustainability. MIS Quarterly, 34(1), 1-21. Retrieved from https://www.misq.org/ downloadable/download/linkSample/link_id/838/

Mihalic, T., \& Buhalis, D. (2013). ICT as a new competitive advantage factor - Case of small transitional hotel sector. Economic and Business Review for Central and South-Eastern Europe, 15(1), 33-56. Retrieved from https://www.researchgate.net/publication/269113660 ICT_as_a_competitive_advantage_factor_-_case_of_small transitional hotel sector

Ollo-López, A., \& Aramendía-Muneta, M.E. (2011). ICT impact on competitiveness, innovation and environment, Telematics and Informatics, 29(2), 204210.

https://doi.org/10.1016/j.tele.2011.08.002

Pekovic, S., Grolleau, G., \& Mzoughi, N. (2018). Environmental investments: too much of a good thing?
International Journal of Production Economics, 197, 297-302.

https://doi.org/10.1016/j.ijpe.2018.01.012

Pham, Q. T. (2010). Measuring the ICT maturity of SMEs. Journal of Knowledge Management Practice, 11(1), 1-14. Retrieved from http:/www.tlainc.com/ artic1223.htm? W PxsVfOoGuGtmAXI-oCgBQ \&ved=0CC4QFjAF\&usg=AFQjCNEnrDICES 9k9ayazP24GqdeTimwQ

Powell, T. C., \& Dent-Micallef, A. (1997). Information technology as competitive advantage: The role of human, business, and technology resources. Strategic Management Journal, 18(5), 375-405.

https://doi.org/10.1002/(SICI)1097-0266(199705) 18:5<375::AID-SMJ876>3.0.CO;2-7

Radu, L. D. (2016). Determinants of green ICT adoption in organizations: a theoretical perspective. Sustainability, $8(8), 731$. https://doi.org/10.3390/su8080731

Sajtos, L. \& Mitev, A. (2007). SPSS kutatási és adatelemzési kézikönvy. (SPSS research and analytics handbook). Budapest, Hungary: Alinea.

Schultze, W., \& Trommer, R. (2012). The concept of environmental performance and its measurement in empirical studies. Journal of Management Control, 22(4), 375-412.

https://doi.org/10.1007/s00187-011-0146-3

Seuring, S., \& Müller, M. (2008). From a literature review to a conceptual framework for sustainable supply chain management. Journal of Cleaner Production, 16(15), 1699-1710.

https://doi.org/10.1016/j.jclepro.2008.04.020

Sheth, J. N., Sethia, N. K., \& Srinivas, S. (2011). Mindful consumption: a customer-centric approach to sustainability. Journal of the Academy of Marketing Science, 39(1), 21-39.

https://doi.org/10.1007/s11747-010-0216-3

Song, M., Fisher, R., Wang, J., \& Cui, L.B. (2018). Environmental performance evaluation with big data: theories and methods. Annual Operations Research, 270(1-2), 459-472.

https://doi.org/10.1007/s10479-016-2158-8

Subburaj, S., \& Kulkarni, S. (2014). Analysis of Green IT Features for Improving Business Performance. International Journal for Infonomics (IJI), 7(1/2), 867873.

https://doi.org/10.20533/iji.1742.4712.2014.0103

Tuni A., Rentizelas A., \& Duffy, A. (2018). Environmental performance measurement for green supply chains: A systematic analysis and review of quantitative methods. International Journal of Physical Distribution \& Logistics Management, 48(8), 765-793. https//:www. doi.org/10.1108/IJPDLM-02-2017-0062

Wang, Y., Sanchez Rodrigues, V., \& Evans, L. (2015). The use of ICT in road freight transport for $\mathrm{CO}_{2}$ reduction - An exploratory study of UK's grocery retail industry. International Journal of Logistics Management, 26(1), $2-29$.

https://doi.org/10.1108/IJLM-02-2013-0021 
Watts, S. (2015). Corporate social responsibility reporting platforms: enabling transparency for accountability. Information Technology and Management, 16(1), 1935 . https://doi.org/10.1007/s10799-014-0192-2

Weber, D. M., \& Kauffman, R. J. (2011). What drives global ICT adoption? Analysis and research directions. Electronic Commerce Research and Applications, 10(6), 683-701. https://doi.org/10.1016/j.elerap.2011.01.001

Yi, L., \& Thomas, H. R. (2007). A review of research on the environmental impact of e-business and ICT. Environment International, 33(6), 841-849. https://doi.org/10.1016/j.envint.2007.03.015

Zahra, S.A., \& George, G. (2002). Absorptive capacity: a review, reconceptualization, and extension. Academy of Management Review, 27(2), 185-203. https://doi.org/10.5465/amr.2002.6587995 